\title{
Phenolic Compounds in Centaurea rupestris Tissues and Their Antiphytoviral Activity
}

\author{
Mirna Ćurković-Perica, ${ }^{*}$ Saša Likić, and Gordana Rusak \\ Department of Biology, Faculty of Science, University of Zagreb, Marulićev trg 9a, 10000 Zagreb, Croatia
}

RECEIVED APRIL 16, 2013; REVISED JANUARY 9, 2014; ACCEPTED JANUARY 14, 2014

\begin{abstract}
Quantitative and qualitative analysis of phenolic compounds in tissue extracts from Centaurea rupestris L. as well as their antiphytoviral activity against Tomato bushy stunt virus was performed. Extracts of flowers, leaves and roots from C. rupestris growing in the wild, as well as extracts from shoots, tissue consisting of callus and shoots and undifferentiated callus grown in vitro, were tested. Between tested extracts predominantly quantitative and only several qualitative differences in phenolics were detected by high performance liquid chromatography. The highest amounts of quercetagetin 3'-methylether-7-O-B-D-glucopyranoside and quercetin were detected in flowers while in leaves the highest amounts of luteolin, caffeic and $p$-coumaric acid were detected. Except for roots, antiphytoviral activity of all other extracts was high, inducing virus inhibition, ranging from 43 to $90 \%$. Simultaneous application of quercetin, caffeic or $p$-coumaric acid with virus decreased the number of lesions indicating that these substances contribute to the antiphytoviral activity of $C$. rupestris extracts. (doi: $10.5562 /$ cca2272)
\end{abstract}

Keywords: Asteraceae, extracts, flavonoids, HPLC, tissue culture, Tomato bushy stunt virus

\section{INTRODUCTION}

Phenolic compounds are highly diverse class of secondary metabolites which have one or more hydroxyl groups attached directly to an aromatic ring or have more than one phenolic hydroxyl groups attached to one or more benzene rings. They occur in almost all organs in nearly all vascular plants. ${ }^{1,2}$ Different physiological roles, which include protection of plants against abiotic and biotic stress, have been attributed to phenolics. ${ }^{3,4}$ Studies of the biological activities of phenolics, in particular flavonoids, have focused for years on their effects on human health ${ }^{5}$, but they are also active against bacteria, fungi, yeasts and viruses. ${ }^{6}$ Their antiphytoviral activity was revealed by several research groups. Methylated flavonoids reduced Tobacco mosaic virus (TMV) infectivity through weakening of the interactions among viral coat protein subunits, which resulted in increased susceptibility of the viral RNA to host RNAses. ${ }^{7}$ Krcatović et al. ${ }^{8}$ demonstrated inhibition of TMV infection by quercetin and vitexin. Quercetin also induced resistance to Potato virus $X$ (PVX) in Chenopodium quinoa ${ }^{9}$ and was active against Tomato ringspot virus ${ }^{10}$ and Cucumber mosaic virus, ${ }^{11}$ while it acted synergistically with ribavirin against Apple stem grooving virus. $^{12}$ Flavonoid quercetagetin
3'-methylether-7-O-ß-D-glucopyranoside (MQ), isolated from the inflorescences of Croatian endemic species Centaurea rupestris $\mathrm{L}^{13}$ interferes with the initiation of Tomato bushy stunt virus (TBSV) infection ${ }^{14}$ and it also has antibacterial and antifungal activities. ${ }^{15}$ The diversity of other phenolics in C. rupestris and their possible antiphytoviral activity has never been tested before. Therefore, our aim was to investigate the content of phenolics in tissues (leaves, flowers and roots) from plants grown in the wild. Furthermore, after propagating C. rupestris in vitro ${ }^{16}$ we wanted to investigate how various in vitro growing conditions affect the content of phenolics compared to the content in tissues of naturally growing plants. In addition to this, we wanted to test the activity of tissue extracts and detected phenolics against TBSV.

\section{EXPERIMENTAL}

\section{Plant Material and Plant Culture in vitro}

Flowers, leaves and roots of $C$. rupestris L. plants were collected from a natural habitat in Uvala Scott near Kraljevica (Croatian northern coastal region). A voucher specimen is deposited in the herbarium of the Faculty of Science, Department of Biology, University of

\footnotetext{
* Author to whom correspondence should be addressed. (E-mail: mirna.curkovic-perica@biol.pmf.hr)
} 
Zagreb, Croatia. We examined the effect of nutrient media supplemented with different combinations of plant growth regulators or different concentrations of inorganic ions on the qualitative and quantitative content of phenolics in C. rupestris tissues grown in vitro. Shoots were propagated on Murashige and Skoog (MS) ${ }^{17}$ basal nutrient medium and on $1 / 2$ MS ( $1 / 2$ concentration of macroelements). ${ }^{16}$ On nodal segments transferred to medium supplemented with different combinations of plant growth regulators two different types of calli developed. Calli were subcultured and named tissue line $\mathrm{G}$ and undifferentiated callus. A tissue line $\mathrm{G}$, consisting of callus and shoots, was produced on MS medium supplemented with indole-3-butyric acid (IBA; $1.5 \mathrm{mg} \mathrm{dm}^{-3}$ ) and 6-benzylaminopurine (BA; $1 \mathrm{mg} \mathrm{dm}^{-3}$ ). Shoots produced by line $\mathrm{G}$ never elongated more than $2 \mathrm{~cm}$. Undifferentiated callus (UC) was induced on the medium supplemented with 2,4-dichlorophenoxyacetic acid $\left(2,4-\mathrm{D} ; 1 \mathrm{mg} \mathrm{dm}^{-3}\right)$ and BA $\left(1 \mathrm{mg} \mathrm{dm}^{-3}\right)$ in the third subculture. Tissues induced on the media with plant growth regulators and shoots grown on MS and $1 / 2$ MS were subcultured at four week intervals. The $\mathrm{pH}$ of the media was adjusted to 5.7 before autoclaving at $118 \mathrm{kPa}$ and $120{ }^{\circ} \mathrm{C}$ for $20 \mathrm{~min}$. The cultures were incubated at $22 \pm 2{ }^{\circ} \mathrm{C}$ under a $16 \mathrm{~h}$ photoperiod $(40 \mathrm{~W}$ fluorescent light, $\left.80 \mathrm{mmol} \mathrm{m}^{-2} \mathrm{~s}^{-1}\right)$. Tissue samples from the $3^{\text {rd }}, 4^{\text {th }}$ and $5^{\text {th }}$ subcultures were air dried. Each extract was prepared from the plant material grown on the same medium and collected through three subcultures.

\section{Extraction and Hydrolysis}

Air-dried plant tissue ( $2 \mathrm{~g}$ ) was powdered using mortar and pestle and percolated with $15 \times 10^{-3} \mathrm{dm}^{3}$ of methanol. The methanolic extract was then evaporated under vacuum to $2 \mathrm{~g}$ weight $(1: 1, w / w)$. The methanolic extract was centrifuged for $10 \mathrm{~min}$ at $11.000 \mathrm{~g}$ in order to remove residual debris. Supernatant was removed and used in subsequent experiments. In order to hydrolyze obtained extracts hydrochloric acid was added in the final concentration of $1.2 \mathrm{~mol} \mathrm{dm}^{-3}$. The mixture was further submitted to hydrolysis at $80{ }^{\circ} \mathrm{C}$ in a water bath for $30 \mathrm{~min}$. Obtained, non-hydrolyzed and hydrolyzed extracts were used in subsequent spectrophotometric and chromatographic analysis.

\section{Spectrophotometrical Quantification of Total Flavo- noids}

Aluminium chloride colorimetric method was used for flavonoids determination. ${ }^{18}$ However, we modified this method and designed it as a 96-well microplate assay for estimation of total flavonoid (TF) content in prepared extracts. This way it consumes much less reagents and solvents and it can handle more samples in smaller quantities at the same time making the method more efficient. Each extract $\left(25 \times 10^{-6} \mathrm{dm}^{3}\right)$ was separately mixed with $60 \times 10^{-6} \mathrm{dm}^{3}$ of methanol, $5 \times 10^{-6} \mathrm{dm}^{3}$ of $10 \%$ aluminium chloride, $45 \times 10^{-6} \mathrm{dm}^{3}$ of $1 \mathrm{~mol} \mathrm{dm}^{-3}$ potassium acetate and $115 \times 10^{-6} \mathrm{dm}^{3}$ of distilled water. The mixture was left in dark at room temperature for $30 \mathrm{~min}$ and the absorbance of the reaction mixture was measured at $405 \mathrm{~nm}$ with FLUOstar OPTIMA plate reader (BMG Labtech $\mathrm{GmbH}$, Offenburg, Germany). The calibration curve was prepared according to quercetin solutions in methanol at concentrations 12.5 to $100 \mathrm{mg} \mathrm{dm}^{-3}$. Total flavonoids were expressed as means in $\mathrm{mg}$ of quercetin equivalents per $\mathrm{g}$ of sample dry weight.

\section{High Performance Liquid Chromatography Analysis}

The following phenolic substances were assayed: (flavonols) MQ, myricetin, quercetin, galangin and kaempferol, (flavone) luteolin, (flavanon) naringenin, (phenolic acids) $p$-coumaric, caffeic and cinnamic acid (Figure 1). Authentic standards were purchased from Fluka (Germany) and Sigma-Aldrich (Germany) for all the above mentioned compounds except MQ. MQ was isolated from flowers of $C$. rupestris, according to the procedure described by Rusak et al. ${ }^{15}$ High performance liquid chromatography analysis (HPLC) system (Agilent 1100 Series) equipped with a quaternary pump, multi-wave UV/Vis detector, autosampler, fraction collector, $5 \mu \mathrm{m}$ Zorbax Rx-C18 guard column (4.6 $\times$ $12.5 \mathrm{~mm}$, Agilent Technologies) and a five $\mu \mathrm{m}$ Zorbax Rx-C18 column $(4.6 \times 75 \mathrm{~mm}$, Agilent Technologies $)$ was used for all analyses. Phenolic compounds were identified and quantified by UV/Vis spectroscopy and by HPLC chromatography with authentic standards. Absorbance was measured at 268, 280, 310, 350 and $374 \mathrm{~nm}$. The injection volume was $20 \times 10^{-6} \mathrm{dm}^{3}$ and the flow rate $1.0 \times 10^{-3} \mathrm{dm}^{3} \mathrm{~min}^{-1}$ at $35^{\circ} \mathrm{C}$. Elution profile consisted of solvent A (deionised water containing 0.05 $\%$ trifluoroacetic acid), solvent B (20\% methanol containing $0.05 \%$ trifluoroacetic acid), solvent C (70\% methanol containing $0.05 \%$ trifluoroacetic acid) and solvent D (100\% methanol). The solvent composition (A/B / C / D) changed according to the following gradient: $80 / 20 / 0 / 0$ at $0 \mathrm{~min}, 0 / 100 / 0 / 0$ at $4 \mathrm{~min}, 0 / 0 / 100 / 0$ at $23 \mathrm{~min}, 0 / 0 / 0 / 100$ at $27 \mathrm{~min}, 0 / 0 / 0 / 100$ at $32 \mathrm{~min}$ and finally $80 / 20 / 0 / 0$ at $33 \mathrm{~min}$. Concentrations of tested phenolics were determined, based on the chromatographic data of the standards. The calibration curves (peak area $v s$. concentration) for individual compounds were obtained for a wide concentration range.

\section{Virus Propagation}

TBSV was propagated in a systemic host, Nicotiana megalosiphon Van Heurck \& Müll. Arg. Systemically 
<smiles>O=C(O)/C=C/c1ccc(O)c(O)c1</smiles>

caffeic acid<smiles>O=c1cc(-c2ccc(O)c(O)c2)oc2cc(O)cc(O)c12</smiles>

luteolin<smiles>O=c1c(O)c(-c2ccc(O)cc2)oc2cc(O)cc(O)c12</smiles><smiles>O=C(O)/C=C/c1ccc(O)cc1</smiles>

$p$-coumaric acid<smiles>O=C(O)/C=C/c1ccccc1</smiles>

cinnamic acid<smiles>O=c1c(O)c(-c2ccc(O)c(O)c2)oc2cc(O)cc(O)c12</smiles><smiles>O=c1c(O)c(-c2ccccc2)oc2cc(O)cc(O)c12</smiles><smiles>O=C1C[C@H](c2ccc(O)cc2)Oc2cc(O)cc(O)c21</smiles><smiles>O=c1c(O)c(-c2cc(O)c(O)c(O)c2)oc2cc(O)cc(O)c12</smiles><smiles>COc1cccc(-c2oc3cc(C4OC[C@H](CO)[C@@H](O)[C@H](O)[C@H]4O)c(O)c(O)c3c(=O)c2O)c1</smiles>

quercetagetin 3'-methylether-7-O- $\beta$-D-glucopyranoside (MQ)

Figure 1. Chemical structures of investigated phenolic compounds.

infected leaves were ground in $0.06 \mathrm{~mol} \mathrm{dm}{ }^{-3}$ phosphate buffer, $\mathrm{pH} 7.0(1: 1, w / v)$ and centrifuged at low speed to prepare the virus inoculum. This inoculum was diluted with inoculation buffer to yield 80-90 lesions per inoculated leaf of Nicotiana glutinosa L. Prior to virus inoculation leaves were dusted with carborundum.

\section{Application of Extracts and Phenolic Compounds}

Methanolic tissue extract $\left(0.5 \times 10^{-3} \mathrm{dm}^{3}\right)$, prepared as described previously, was evaporated and the residue was dissolved in virus inoculum $\left(0.5 \times 10^{-3} \mathrm{dm}^{3}\right)$. This mixture was inoculated on $N$. glutinosa leaf halves (10 plants, 2 leaves per plant). The remaining leaf halves were inoculated with virus inoculum only. To test the effect of wounding on phenolics, whole leaves were mock inoculated with phosphate buffer $\left(0.06 \mathrm{~mol} \mathrm{dm}^{-3}\right.$,
$\mathrm{pH}$ 7.0). To determine the effects of phenolics detected in the tested tissue, and to determine the effects of other representative phenolics of phenylpropanoid biosynthetic pathway on TBSV infection, the system same as previously described was used. Anti-TBSV activity of representative phenolics of phenylpropanoid biosynthetic pathway was tested in order to determine whether they exhibit anti-TBSV activity or cause adverse effects. Before inoculation caffeic, cinnamic and $p$-coumaric acid as well as galangin, kaempferol, luteolin, MQ, myricetin, naringenin and quercetin were added to the virus inoculum separately, in the final concentration of $10 \mathrm{mg} \mathrm{dm}^{-3}$.

In addition to that, in the case of caffeic acid, $p$-coumaric acid, luteolin and quercetin, an additional experiment was done in which the concentration of each 
Table 1. Different naturally and in vitro grown tissues from Centaurea rupestris and the quantitative analysis of phenolic compounds in nonhidrolyzed tissue extracts. The effect of specified extracts on Tomato bushy stunt virus infection in Nicotiana glutinosa is expressed as inhibition percentage (\%)

\begin{tabular}{|c|c|c|c|c|c|}
\hline $\begin{array}{l}\text { Medium and hormone } \\
\text { supplement }\left(\mathrm{mg} \mathrm{dm}^{-3}\right)\end{array}$ & Tissue (line) & $\begin{array}{c}\text { Total phenolics }{ }^{(*)} \\
(\%)\end{array}$ & $\begin{array}{c}\text { Inhibition } \\
\text { percentage (\%) }\end{array}$ & $\begin{array}{c}\text { Total } \\
\text { flavonoids }^{(\#)}\end{array}$ & $\begin{array}{l}\text { Caffeic } \\
\text { acid }^{(\#)}\end{array}$ \\
\hline nature & leaf & $30.4 \mathrm{c}$ & 90 & $11.14 \mathrm{~d}$ & $789.84 \mathrm{~d}$ \\
\hline nature & flower & $100 \mathrm{~d}$ & 79 & $50.02 \mathrm{e}$ & $109.18 \mathrm{bc}$ \\
\hline nature & root & $2.7 \mathrm{a}$ & 3 & $1.05 \mathrm{a}$ & $99.34 \mathrm{abc}$ \\
\hline $\mathrm{MS}+\operatorname{IBA}(1,5)+\mathrm{BA}(1)$ & callus + shoots $(G)$ & $7.6 \mathrm{~b}$ & 76 & $2.92 \mathrm{~cd}$ & $33.77 \mathrm{a}$ \\
\hline $\mathrm{MS}+2,4-\mathrm{D}(1)+\mathrm{BA}(1)$ & $\begin{array}{l}\text { undifferentiated callus } \\
\text { (UC) }\end{array}$ & $5.6 \mathrm{ab}$ & 60 & $2.64 \mathrm{bc}$ & $152.13 \mathrm{c}$ \\
\hline $\mathrm{MS} 1 / 2$ & shoots & $3.6 \mathrm{a}$ & 43 & $1.35 \mathrm{ab}$ & $64.26 \mathrm{ab}$ \\
\hline MS & shoots & $3.5 \mathrm{a}$ & 43 & $1.73 \mathrm{ab}$ & $48.85 \mathrm{ab}$ \\
\hline $\begin{array}{l}\text { Medium and hormone } \\
\text { supplement }\left(\mathrm{mg} \mathrm{dm}^{-3}\right)\end{array}$ & Tissue (line) & $\begin{array}{l}\text { Coumaric } \\
\operatorname{acid}^{(\#)}\end{array}$ & Quercetin $^{(\#)}$ & Luteolin $^{(\#)}$ & $\mathrm{MQ}^{(\#)}$ \\
\hline nature & leaf & $74.85 \mathrm{e}$ & $15.53 \mathrm{~b}$ & $390.28 \mathrm{~b}$ & $65.49 \mathrm{~b}$ \\
\hline nature & flower & $8.36 \mathrm{bc}$ & $40.15 \mathrm{c}$ & nd & $6917.72 \mathrm{c}$ \\
\hline nature & root & $13.36 \mathrm{~d}$ & blq & blq & blq \\
\hline $\mathrm{MS}+\operatorname{IBA}(1,5)+\mathrm{BA}(1)$ & callus + shoots $(G)$ & $10.22 \mathrm{~cd}$ & $7.70 \mathrm{a}$ & $4.16 \mathrm{a}$ & $89.18 \mathrm{~b}$ \\
\hline $\mathrm{MS}+2,4-\mathrm{D}(1)+\mathrm{BA}(1)$ & $\begin{array}{l}\text { undifferentiated callus } \\
\text { (UC) }\end{array}$ & $7.61 \mathrm{bc}$ & blq & nd & nd \\
\hline $\mathrm{MS} 1 / 2$ & shoots & $5.6 \mathrm{ab}$ & $5.05 \mathrm{a}$ & $10.60 \mathrm{a}$ & blq \\
\hline MS & shoots & $3.73 \mathrm{a}$ & $3.54 \mathrm{a}$ & $2.99 \mathrm{a}$ & $13.81 \mathrm{a}$ \\
\hline
\end{tabular}

The same letter within a column denotes no significant $(p<0.05)$ difference between investigated tissues (Tukey-Kramer minimum significant difference test).

blq - below limit of quantification.

nd - not detected.

MQ - quercetagetin 3'-methylether-7-O-ß-D-glucopyranoside.

${ }^{(*)}$ The amount of total phenolics in studied tissues was expressed relative to the content of total phenolics in flowers.

(\#) All values are expressed as means in $\mu \mathrm{g}$ per gram of sample dry weight except for total flavonoids which are expressed as means in $\mathrm{mg}$ of quercetin equivalents per gram of sample dry weight.

mentioned substance was adjusted according to the highest endogenous levels measured in the tissues of $C$. rupestris by HPLC method (caffeic acid - $200 \mathrm{mg} \mathrm{dm}^{-3}$, $p$-coumaric acid - $400 \mathrm{mg} \mathrm{dm}^{-3}$, luteolin - $1 \mathrm{~g} \mathrm{dm}^{-3}$, quercetin - $300 \mathrm{mg} \mathrm{dm}^{-3}$ ). Local lesions on $N$. glutinosa were counted three days post inoculation. All experiments were repeated three times.

\section{RESULTS AND DISCUSSION}

It is known that individual plants within a species produce and accumulate phenolics depending on plants growth and reproductive stage, the plant tissue tested, the extent of tissue differentiation and the type of stress applied. ${ }^{19-22}$ Production of phenolics can also be influenced by nutrients and plant growth regulators in the medium. $^{23,24}$

Quantitative and qualitative analysis of phenolics was performed on extracts from shoots grown in vitro on MS and $1 / 2$ MS, undifferentiated callus and tissue line $G$ as well as from flowers, leaves and the roots of naturally growing plants. The highest amount of total phenolics
(TP) was determined in naturally growing flowers followed by naturally growing leaves. Likewise, flowers and leaves from naturally growing plants had the highest content of flavonoids. The content of flavonoids in extracts from in vitro grown tissues was significantly lower than in naturally grown leaves or flowers. Observed differences between naturally and in vitro grown plants could be due to UV exposition since it is known that exposure to UV radiation increases the level of flavonoids in plants. ${ }^{25}$ Roots of naturally growing plants contained the lowest amount of flavonoids among all studied tissues (Table 1). Yet, this is not surprising because different tissues within the same plant can produce different phenolics in different concentrations. ${ }^{26,27}$

Although cultures of differentiated organs often produce more secondary metabolites than callus cultures $^{28,29}$ in our experiments, tissue line $\mathrm{G}$, consisting of undifferentiated tissue and shoots, contained significantly higher concentrations of $\mathrm{TP}$ and $\mathrm{TF}$ than completely differentiated in vitro grown shoots. Content of TP and TF between tissue lines G and UC was not significantly different. However, significant differences 
were found in the concentration of caffeic acid, quercetin, luteolin and MQ between these tissue lines (Table 1). It was previously shown that the production of phenolics in cultures is highly dependent on plant growth regulators ${ }^{30}$ and that growth regulators have higher impact on phenolics' production than changes of nutrient salt concentration in basal medium. ${ }^{24}$ The results obtained for in vitro grown tissues are in accordance with these findings. Furthermore, Naz et al. ${ }^{23}$ showed that total phenolic content in both nonmorphogenic and morphogenic calli of chick pea is higher when compared to respective explant tissue.

The intensity of anti-TBSV activity was tissue dependent, but there was no correlation between TP or $\mathrm{TF}$ and the intensity of inhibition of lesion formation in all studied samples. Leaf and flower samples exhibited very high antiphytoviral activity which suggested that phenolic compounds could have a significant role in antiphytoviral activity. However, even though TP and TF contents in shoots grown on MS and $1 / 2 \mathrm{MS}$ medium, $\mathrm{UC}$ and tissue line $\mathrm{G}$ were significantly lower than in naturally grown tissues, their antiviral activity was high, ranging from 43 to $76 \%$ of inhibition. Since plant in vitro cultures often produce phenolics that do not occur in the original plants and production of flavonoids can be influenced by nutrients in the medium, ${ }^{23,24,31,32}$ we searched for qualitative and quantitative changes of active phenolic substances that might have contributed to the antiviral activity. This was done by HPLC which enabled us to detect and quantify distinct phenolics in all tested tissues (Table 1). Our research encompassed seven flavonoids (myricetin, quercetin, galangin, kaempferol, luteolin, naringenin and MQ) and three phenolic acids (caffeic, $p$-coumaric and cinnamic acid) which were already found in genus Centaurea and in the family Asteraceae. ${ }^{14,33,34}$ Our analyses revealed that MQ was the predominant flavonoid in flowers and its amount in flowers was approximately two orders of the magnitude higher than in the leaves of naturally growing plants, in shoots grown in vitro on MS and in tissue line G. MQ was not detected in UC while in roots and in shoots grown in vitro on MS $1 / 2$ the content of MQ was below the limit of quantification. Furthermore, after hydrolysis of extracts, we were able to detect traces of myricetin and kaempferol in flower extracts and in extracts from shoots grown in vitro. Naringenin was also detected in traces, but only in shoots grown in vitro. Galangin was not detected in any of the tested tissues. Possible explanation for such a low content of some of the tested flavonoids (which were therefore not detected by HPLC or were below the limit of quantification) is, as previously described, ${ }^{35,36}$ probable fast conversion to other flavonoids (which were not tested in our experiments). Such a hypothesis is supported by the fact that cinnamic acid, which is a precursor of $p$-coumaric acid and caffeic acid, was not detected in any of the tested tissues, while caffeic and $p$-coumaric acid were detected in all tested tissues. The highest amount of both compounds was detected in leaves (Table 1).

Even though the level of MQ in flowers was two orders of the magnitude higher than in leaves of naturally growing plants, extracts of leaves had higher antiviral activity. Other extracts, except the one from roots, also exhibited antiviral activity, ranging from 43 to $76 \%$, although the concentration of MQ in them was significantly lower than in flowers. No correlation was observed between the content of detected phenolics and the observed anti-TBSV activity. This prompted us to test the anti-TBSV activity of representative phenolics of phenylpropanoid biosynthetic pathway in order to

Table 2. Effect of phenolic compounds on Tomato bushy stunt virus observed through changes in lesions number on Nicotiana glutinosa leaves and expressed as an increase (positive numbers) or decrease (negative numbers) of inhibition percentage (presence and content of phenolic acids and flavonoids in C. rupestris tissues was confirmed by high performance liquid chromatography (HPLC)

\begin{tabular}{cc}
\hline $\begin{array}{c}\text { Tested compounds } \\
\text { in virus inoculum }\end{array}$ & Inhibition percentage (\%) \\
\hline Phenolic acids $^{(\mathrm{b}}$ & $22^{(\mathrm{d})}$ \\
caffeic acid $^{(\mathrm{s})}$ & $70^{(\mathrm{d})}$ \\
caffeic acid $^{(\mathrm{c})}$ & $-45^{(\mathrm{d})}$ \\
cinnamic acid $^{(\mathrm{a})}$ & 1 \\
p-coumaric acid & \\
p-coumaric acid $^{(\mathrm{c})}$ & $79^{(\mathrm{d})}$ \\
Flavonoids $^{(\mathrm{a})}$ & \\
galangin $^{(\mathrm{d})}$ & $44^{(\mathrm{d})}$ \\
kaempferol $^{\left(\mathrm{a}^{\prime}\right)}$ & 6 \\
luteolin $^{(\mathrm{b})}$ & -9 \\
luteolin $^{(\mathrm{c})}$ & -42 \\
MQ $^{(\mathrm{b})}$ & -37 \\
myricetin $^{\left(\mathrm{a}^{\prime}\right)}$ & 6 \\
naringenin $^{\left(\mathrm{a}^{\prime}\right)}$ & $-55^{(\mathrm{d})}$ \\
quercetin $^{(\mathrm{b})}$ & $17^{(\mathrm{d})}$ \\
quercetin $^{(\mathrm{c})}$ & $72^{(\mathrm{d})}$ \\
\hline
\end{tabular}

MQ - quercetagetin 3'-methylether-7-O-ß-D-glucopyranoside. (a) Compound was not detected by HPLC or (a') was below the limit of quantification in C. rupestris tissues.

${ }^{\text {(b) }}$ Concentration of tested compounds in virus inoculums was adjusted to $10 \mathrm{mg} \mathrm{dm}^{-3}$.

${ }^{\text {(c) }}$ Concentration of tested compounds in virus inoculums was adjusted according to the highest endogenous levels measured in the tissues of C. rupestris (caffeic acid $-200 \mathrm{mg} \mathrm{dm}^{-3}$, $p$-coumaric acid - $400 \mathrm{mg} \mathrm{dm}^{-3}$, luteolin $-1 \mathrm{~g} \mathrm{dm}^{-3}$, quercetin $300 \mathrm{mg} \mathrm{dm}^{-3}$ ).

(d) Denotes significant decrease or increase of inhibition percentage $(p<0.05$, paired t-test). 
determine whether they exhibit anti-TBSV activity or cause adverse effects. Therefore, we tested anti-TBSV activity of three phenolic acids and 7 flavonoids in the experiment of simultaneous inoculation with virus inoculum. It was previously shown that application of $1 \mathrm{~g} \mathrm{dm}^{-3} \mathrm{MQ}$, which approximately corresponds to the highest concentration of MQ detected in flowers, has strong anti-TBSV activity. ${ }^{14}$ However, two orders of the magnitude lower concentration of MQ was detected in leaves and tissue line $G$ (Table 1) and therefore this lower concentration of MQ $\left(10 \mathrm{mg} \mathrm{dm}^{-3}\right)$ was also tested for its anti-TBSV activity. In our experiment, caffeic acid $\left(10 \mathrm{mg} \mathrm{dm}^{-3}\right.$ and $\left.200 \mathrm{mg} \mathrm{dm}^{-3}\right), p$-coumaric acid (only when applied in the concentration which corresponds to the highest one detected in the tissue $400 \mathrm{mg} \mathrm{dm}^{-3}$ ), quercetin ( $10 \mathrm{mg} \mathrm{dm}^{-3}$ and $300 \mathrm{mg} \mathrm{dm}^{-3}$ ) and galangin $\left(10 \mathrm{mg} \mathrm{dm}^{-3}\right)$ exhibited significant antiTBSV activity which was observed through a decreased number of lesions. On the other hand, cinnamic acid and naringenin significantly facilitated TBSV infection which was observed through increased number of lesions while simultaneous inoculation of kaempferol, luteolin, myricetin or MQ $\left(10 \mathrm{mg} \mathrm{dm}^{-3}\right)$ with the virus did not result in a significant increase or decrease in the number of lesions (Table 2). Obtained results suggest that the observed anti-TBSV activity should be regarded as an interplay of phenolics present in distinct tissue, their concentrations and utilisation.

\section{CONCLUSION}

Naturally growing flowers and leaves of C. rupestris had significantly higher content of total phenolics and flavonoids compared to roots and to all in vitro grown tissues. Antiphytoviral activity and concentrations of phenolic compounds in all extracts were tissue dependent. Quercetin, $p$-coumaric and caffeic acid contributed to antiphytoviral activity of $C$. rupestris tissues, but other secondary metabolites might affect (inhibit or contribute to) this activity, too.

Acknowledgements. This research was supported by the Ministry of Science, Education and Sport of the Republic of Croatia. The authors declare that they have no conflict of interest.

\section{REFERENCES}

1. S. Martens, A. Preuss, and U. Matern, Phytochemistry 71 (2010) 1040-1049.

2. I. E. Jordon-Thaden and S. M. Louda, Biochem. Syst. Ecol. 31 (2003) 1353-1396

3. R. A. Dixon, Nature 411 (2001) 843-847.
4. D. Treutter, Plant Biol. 7 (2005) 581-591.

5. G. Di Carlo, N. Mascolo, A. A. Izzo, and F. Capasso, Life Sci. 65 (1999) 337-353

6. T. P. T. Cushnie and A. J. Lamb, Int. J. Antimicrob. Ag. 26 (2005) 343-356.

7. C. J. French, M. Elder, F. Leggett, R. K. Ibrahim, and G. H. N. Towers, Can. J. Plant Pathol. 13 (1991) 1-6.

8. E. Krcatović, G. Rusak, N. Bezić, and M. Krajačić, Acta Virol. 52 (2008) 119-124.

9. V. S. Verma, Zbl. Bakt. Abt. II Bd. 128 (1973) 467-472.

10. B. Malhotra, J. C. Onyilagha, B. A. Bohm, G. H. N. Towers, D. James, J. B. Harborne, and C. J. French, Phytochemistry 43 (1996) 1271-1276.

11. G. Rusak, M. Krajačić, M. Krsnik-Rasol, and H. O. Gutzeit, J. Plant Dis. Protect. 114 (2007) 145-150.

12. D. James, P. A. Trytten, D. J. Mackenzie, G. H. N. Towers, and C. J. French, Ann. Appl. Biol. 131 (1997) 459-470.

13. Z. Pavletić and I. Trinajstić, Acta. Bot. Croatica 42 (1983) $137-$ 143.

14. G. Rusak, M. Krajačić, and N. Pleše, Antiviral Res. 36 (1997) 125-129.

15. G. Rusak, N. Robinson, and S. Pepeljnjak, Acta Biol. Cracov. Bot. 44 (2002) 169-174.

16. M. Ćurkovic-Perica, Acta Biol. Cracov. Bot. 45 (2003) 131-134.

17. T. Murashige and F. Skoog, Physiol. Plant. 15 (1962) 473-497.

18. C. C. Chang, M. H. Yang, H. M. Wen, and J. C. Chern, J Food Drug. Anal. 10 (2002) 178-182.

19. R.A. Dixon and N. L. Paiva, Plant Cell 7 (1995) 1085-1097.

20. P. Broun, Curr. Opin. Plant Biol. 8 (2005) 272-279.

21. N. V Zagoskina, V. G. Fedoseeva, L. V Frolova, N. D. Azarenkova, and M. N. Zaprometov, Russ. J. Plant Physiol. 41 (1994) 672-676.

22. R. Vuković, N. Bauer, and M. Ćurković-Perica, Plant Sci. 199-200 (2013) 18-28.

23. S. Naz, A. Ali, and J. Iqbal, Pak. J. Bot. 40 (2008) 2525-2539.

24. M. Masoumian, A. Arbakariya, A. Syahida, and M. Maziah, J. Med. Plants Res. 5 (2011) 1564-1574.

25. R. W. Hofmann, B. D. Campbell, S. J. Bloor, E. E. Swinny, K. R. Markham, K. G. Ryan, and D. W. Fountain, Plant Cell Environ. 26 (2003) 603-612.

26. J. Murata, J. Roepke, H. Gordon, and V. De Luca, Plant Cell 20 (2008) 524-542.

27. C. K. Kleindt, R. Stracke, F. Mehrtens, and B. Weisshaar, $B M C$ Res. Notes 3 (2010) 255-267.

28. S. R. Rao and G. A. Ravishankar, Biotechnol. Adv. 20 (2002) 101-153.

29. A. Jedinák, J. Faragó, I. Pšenáková, and T. Maliar, Biologia 59 (2004) 697-710.

30. I. Ionkova, Phcog. Mag. 5 (2009) 92-97.

31. H. Yamamoto, K. Yan, K. Ieda, T. Tanaka, M. Iinuma, and M. Mizuno, Phytochemistry 33 (1993) 841-846.

32. A. C. P. Dias, F. A. Tomás-Barberán, M. Fernandes-Ferreira, and F. Ferreres, Phytochemistry 48 (1998) 1165-1168.

33. G. Flamini, E. Antognoli, and I. Morelli, Phytochemistry 57 (2001) 559-564

34. G. C. Obute and G. O. Adubor, Ethnobotanical Leaflets 11 (2007) 173-194.

35. R. Lukačin, F. Wellmann, L. Britsch, S. Martens, and U. Matern, Phytochemistry 62 (2003) 287-292.

36. K. Marinova, L. Pourcel, B. Weder, M. Schwarz, D. Barron, J.-M. Routaboul, I. Debeaujon and M. Klein, Plant Cell 19 (2007) 2023-2038. 